\title{
PELATIHAN PUBLIKASI JURNAL HASIL PENELITIAN TINDAKAN KELAS BAGI GURU SLB N 1 BANTUL YOGYAKARTA
}

\author{
Luqman Hidayat ${ }^{1}$, Faiz Noormiyanto ${ }^{2}$ \\ 1,2 Pendidikan Luar Biasa, Universitas PGRI Yogyakarta \\ Jl. PGRI 1 No 117 Yogyakarta \\ ${ }^{1}$ Email: luqman@upy.ac.id \\ ${ }^{2}$ Email: faiz@upy.ac.id
}

\begin{abstract}
ABSTRAK
Kegiatan ini bertujuan untuk memberikan pengetahuan kepada para guru dan mengatasi kesulitan dalam publikasi artikel hasil penelitian tindakan kelas (PTK) ke Jurnal berbasis OJS (Open Journal System) dilingkungan SLB Negeri 1 Bantul. Target yang ingin dicapai melalui kegiatan ini adalah meningkatnya kompetensi guru dalam membuat/menyususn artikel hasil penelitian tindakan kelas dan memberikan keterampilan dalam submit jurnal berbasis OJS. Selain kompetensi guru yang meningkat. Kegiatan pengabdian dilaksanakan melalui beberapa metode pelatihan, yaitu: 1) Metode ceramah, 2) metode tanya jawab, dan 3) metode simulasi. Pelatihan dilaksanakan sebanyak 4 kali secara teori dan praktik, hal ini dilakukan agar para guru tidak hanya memahami teorinya saja, namun guru juga dapat mandiri dalam membuat artikel dan submit jurnal OJS dengan baik dan benar. Hasil yang dicapai adalah guru dapat menyusun sebuah artikel hasil PTK dan menunggahnya ke jurnal OJS.
\end{abstract}

Kata Kunci: pelatihan guru, ptk, publikasi jurnal

\section{JOURNAL PUBLICATION TRAINING RESEARCH RESULTS CLASS ACTION FOR TEACHERS SLB N 1 BANTUL YOGYAKARTA}

\begin{abstract}
This training gives knowledge to teachers in Special Education Needs School 1 Bantul to overcome difficulties in publishing articles on the results of classroom action research (CAR) to OJS-based journals (Open Journal System). The target to be achieved through this activity is to increase teacher competence in making / compiling articles on the results of classroom action research and providing skills in submitting OJS-based journals. Besides increasing teacher competence. Service activities carried out through several training methods, namely: 1) lecture method, 2) question and answer method, and 3) simulation method. The training was carried out 4 times in theory and practice, this was done so that the teachers not only understood the theory, but the teacher could also be independent in making articles and submit OJS journals properly. The results achieved are the teacher can compile an PTK result article and upload it to the OJS journal.
\end{abstract}

Keywords: teacher training, classroom action research, journal publications 


\section{PENDAHULUAN}

Kualitas Pendidikan di suatu bangsa sangat tergantung pada posisi guru. Guru professional selalu siap menghadapi perubahan/dinamika Pendidikan. Pendidikan Indonesia harus dapat menjawab tantangan global agar tidak tertinggal dengan bangsa lain. Salah satu cara untuk meningkatkan kompetensi dan profesionalisme guru adalah dengan melaksanakan penelitian tindakan kelas (PTK). Sesuai peraturan yang tertuang pada Undang-Undang No. 14 Tahun 2005 tentang guru dan dosen, seorang gutu wajib memiliki kualifikasi akademik, sehat jasmani dan rohani, memiliki kompetensi, serta memiliki sertifikasi pendidik. Salah satu kompetensi yang wajib dimiliki oleh seorang guru adalah kompetensi professional. Peningkatan kompetensi professional di lingkungan sekolah atau kelas dapat dengan melakukan penelitian tindakan kelas (PTK). Terdapat dua manfaat yang didapat guru ketika melakukan penelitian tindakan kelas, yaitu data meningkatkan kemampuan/peforma guru kelas dalam kegiatan mengembangan profesinya dan memperbaiki kegiatan pembelajaran. Menjadi seorang guru yang professional seyogyanya juga menjadi seorang peneliti. Karena di dalam kelas guru terkadang mendapatkan masalah terkait dengan perkembangan peserta didik, misalkan saja masalah dalam afektif, kognitif, dan psikomotor. Guru sebagai orang yang terdekat dengan peserta didik harus menjadi agen yang dapat menyelesaikan masalah di dalam kelas/pembelajaran. SLB Negeri 1 Bantul, merupakan sekolah rujukan di Provinsi Daerah Istimewa Yogyakarta. Di sekolah ini, mempunyai banyak guru yang telah melaksanakan penelitian tindakan kelas. Namun banyaknya penelitian di sekolah tersebut tidak berbanding lurus dengan hasil luaran penelitian yaitu dalam bentuk artikel/jurnal. Dalam kurun waktu 3 tahun terakhir, di lingkungan SLB N 1 Bantul mampu menghasilkan 40 judul penelitian tindakan kelas dari guru. Namun tak satupun yang diterbitkan menjadi jurnal. Padahal, jurnal hasil penelitian dapat membantu guru dalam memperoleh angka kredit yang dapat digunakan untuk kenaikan pangkat. Menjadi seorang guru profesional harus selalu mengembangkan diri untuk memenuhi tuntutan dalam tugasnya sebagai pendidik. Penelitian tindakan kelas merupakan salah satu cara untuk mengembangkan diri sebagai guru yang professional. Guru juga harus memperluas literasi melalui khasanah ilmu pendidikan, misalkan menambah wawasan melalui jurnal penelitian yang dibuat oleh peneliti lain. Perkembangan ilmu pengetahuan tidak hanya tertuang pada buku saja, namun juga tertuang pada jurnal-jurnal yang telah dibaut oleh praktisi maupun peneliti. Hasil penelitian yang dilaksanakan guru di lingkungan SLB N 1 Bantul perlu didorong agar terbit dalam jurnal agar penelitiannya dapat dibaca oleh 
orang lain dan turut menambah berkintribusi dalam bidang IPTEK dari sudut pandang pendidikan luar biasa

\section{METODE PELAKSANAAN}

Pelatihan guru dalam pembuatan artikel bersumber dari penelitian tindakan kelas dilaksanakan pada 22,23,24,27 Mei 2019. Pelaksanaan pelatihan dilakukan di lingkungan SLB Negeri 1 Bantul Yogyakarta. Kegiatan pelatihan artikel PTK bagi guru ini dilaksanakan secara teori dan praktik, baik secara offline maupun online. Durasi pelatihan selama 4 hari dengan total waktu pelatihan adalah 24 jam. Hari pertama dalam pelatihan dilaksanakan untuk memberi gambaran awal definisi artikel, jurnal, dan tata cara penulisan sesuai dengan ketentuan template jurnal. Hari kedua adalah pelatihan bagaimana cara upload/submit jurnal ke OJS, hari ketiga dan keempat adalah pelatihan penyusunan /pembuatan artikel bersumber dari hasil penelitian tindakan kelas yang telah dibuat sebelumnya. Metode yang dipergunakan dalam kegiatan pelatihan ini adalah sebagai berikut:

1. Metode Ceramah

Metode ceramah ini dipilih karena memberikan penjelasan tentang teori karya tulias ilmiah, jenis, dan tata cara penulisannya. Materi disampaikan langsung oleh pengabdi baik ketua maupun anggota yang berkompeten dalam bidang penelitian tindakan kelas (PTK) dan bidang Pendidikan Luar Biasa (PLB).

2. Metode Tanya Jawab

Metode tanya jawab dalam pengabdian/pelatihan guru ini dilaksanakan secara penuh dari awal hingga akhir ketika menerima penjelasan teori maupun ketika praktik. Namun tidak menutup kesempatan dibuka sesi tanya jawab seluas-luasnya pada awal pertemuan dan di akhir pertemuan untuk mengkonformasi hal apa saja yang menjadi kendala selama pelatihan dan kesuliatan apa saja yang dialami guru dalam menuangkan hasil penelitian ke dalam artikel.

3. Metode Praktik

Metode ini sangat penting diberikan pada saat pelatihan. Kegiatan ini juga dimaksudkan untuk mengkonversi seberapa besar dampak teori jika diimplementasikan secara langsung /praktik yang sesungguhnya. Kegiatan ini juga difungsikan untuk memperkuat pengalaman guru secara nyata dalam membuat artikel, hingga proses submit artikel ke jurnal berbasis OJS.

\section{HASIL DAN PEMBAHASAN}

Seluruh peserta pelatihan publikasi jurnal adalah guru di SLB N 1 Bantul yang 
pernah melaksanakan penelitian tindakan kelas sebelumnya. Terhitung terdapat 17 peserta yang mengikuti pelatihan ini. Guru SLB Negeri 1 Bantul tergolong aktif dan giat dalam membuat penelitian tindakan kelas. Bahkan selama tiga tahun terakhir terdapat 40 judul PTK yang telah dibuat oleh guru. Apabila dirata-rata, maka dalam satu tahun, terdapat 15 judul PTK yang dibuat oleh guru di SLB N 1 Bantul.

Kegiatan pengabdian dimulai dengan pembukaan dan pengarahan oleh kepala SLB N 1 Bantul sebagai mitra dalam pengabdian. Kegiatan pelatihan ini dimaksudkan untuk melatih dan menjaring artikel hasil penelitian tindakan kelas, dengan sasaran guru di lingkungan SLB Negri 1 Bantul.

Tujuan dari kegiatan pelatihan ini adalah untuk membentuk kompetensi guru dalam membuat sebuah karya tulis ilmiah/ jurnal karena seringnya guru dalam membuat penelitian kelas tidak diimbangi dengan banyaknya artikel dalam jurnal yang pernah dibuat. Sehingga banyak tulisan atau penelitian tidak terpublikasi. Padahal guru dituntut aktif dalam membuat PTK dan publikasi jurnal, namun banyak guru yang masih kesulitan karena belum mempunyai pengalaman sebelumnya. Guru yang sudah memiliki banyak pengalaman mengajar ketika masih duduk di bangku perkuliahan belum berkewajiban dalam membuat luaran jurnal ketika menyusun skripsi. Ketika mereka sudah menyelesaikan studi strata 1, banyak dari mereka yang belum memahami mekanisme penyusunan artikel maupun cara untuk submit ke jurnal terutama jurnal berbasis OJS. Sebelumnya guru di SLB Negeri 1 Bantul telah bekerjasama dengan salah satu Universitas di Yogyakarta dalam pembuatan dan publikasi jurnal hasil penelitian tindakan kelas, namun belum mendapatkan informasi lebih lanjut dan kejelasan terkait hasil yang diharapkan. Sehingga banyak guru yang hanya menunggu tanpa kepastian. Harapan dari semua guru adalah artikel dapat termuat dalam jurnal, karena ingin dipergunakan dalam menambah angka kredit untuk kenaikan pangkat/golongan guru. Sehingga guru sangat membutuhkan pelatihan dan kerjasama dengan pihak pengabdi.

Peserta yang hadir dalam pelatihan sejumlah 17 guru dari berbagai spesialisasi mulai dari guru khusus tunanetra, tunarungu, tunagrahita, tunadaksa, tunalaras, autis, berkesulitan belajar. Semua spesialisasi guru pendidikan luar biasa dilibatkan agar terjadi sinkronisasi dan persamaan sudut pandang penelitian tindakan kelas dan penulisan karya tulis ilmiah sesuai dan bersumber pada domain pendidikan luar biasa, termasuk seluruh karakteristik, kebutuhan dari seluruh jenis anak berkebutuhan khusus. Kegiatan pengabdian ini juga 
sejalan dengan Peraturan Bersama Menteri Pendidikan Nasional dan Kepala Badan Kepegawaian Negara Nomor 03/V/Pb/2010 dan Nomor 14 Tahun 2010 tentang Petunjuk Pelaksanaan Jabatan Fungsional Guru Dan Angka Kreditnya.

Target output kegiatan ini yaitu guru-guru di SLB N 1 Bantul memiliki pengetahuan dan keterampilan terkait tahap penulisan artikel sehingga guru dapat memperoleh angka kredit untuk kenaikan pangkat. Tahapan dalam pelatihan yang dilakukan adalah kegiatan pembekalan, pendampingan, implementasi dan evaluasi. Pelatihan ini berlangsung selama dua bulan dimulai pada bulan Mei sampai Juli 2019, kegiatan pelatihan tidak hanya dilakukan secara tatap muka, namun juga dilakukan pendampingan secara online. Hal ini dimaksudkan untuk memberikan pengalaman pembelajaran jarak jauh bagi guru SLB. Berikut ini adalah diagram alir kegiatan dalam tahapan tahapan pelaksanaan kegiatan pengabdian pelatihan penyusunan artikel hasil PTK.

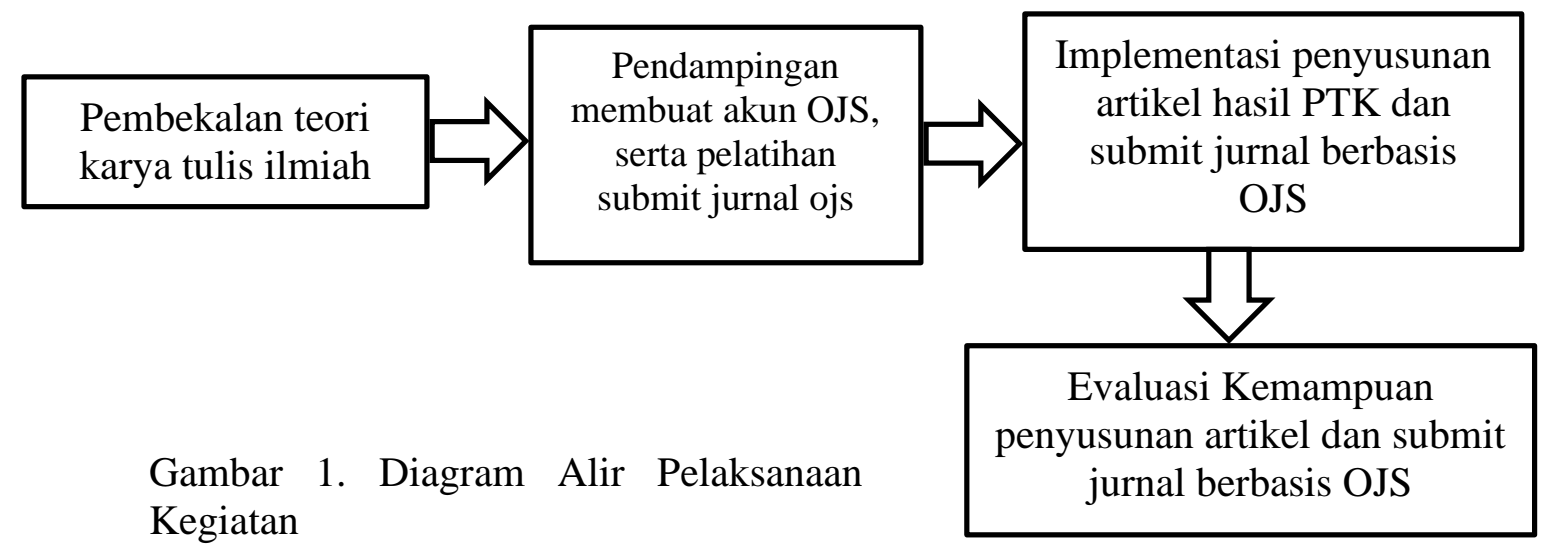

1. Pembekalan

Kegiatan pembekalan pada pelatihan ini bertujuan untuk memberikan bekal konsep kepada guru pendidikan luar biasa di lingkungan SLB Negeri 1 Bantul terkait dengan konsep karya tulis ilmiah, penelitian tindakan kelas, jurnal berbasis online (OJS). Pembekalan pengabdian dilaksanakan selama dua kali pertemuan atau tatap muka. Materi pertama berkaitan dengan ruang lingkup karya tulis ilmiah, sementara materi pada pertemuan kedua adalah memberikan pengetahuan dan meningkatkan kecakapan guru dalam membuat akun / user dalam jurnal online serta pelatihan bagaimana tahapan submit artikel ke jurnal online. Selain itu guru juga dilatih troubleshooting bagaimana mengatasi kesalahan dan mengatasi gangguan teknis terkait dengan kemampuan menggunakan teknologi informasi dan komunikasi yang dilakukan untuk proses submit 
artikel. Proses pembekalan tidak hanya terjadi dalam satu arah, namun juga menjadi sarana diskusi/FGD bagi guru terkait dengan publikasi jurnal hasil PTK.

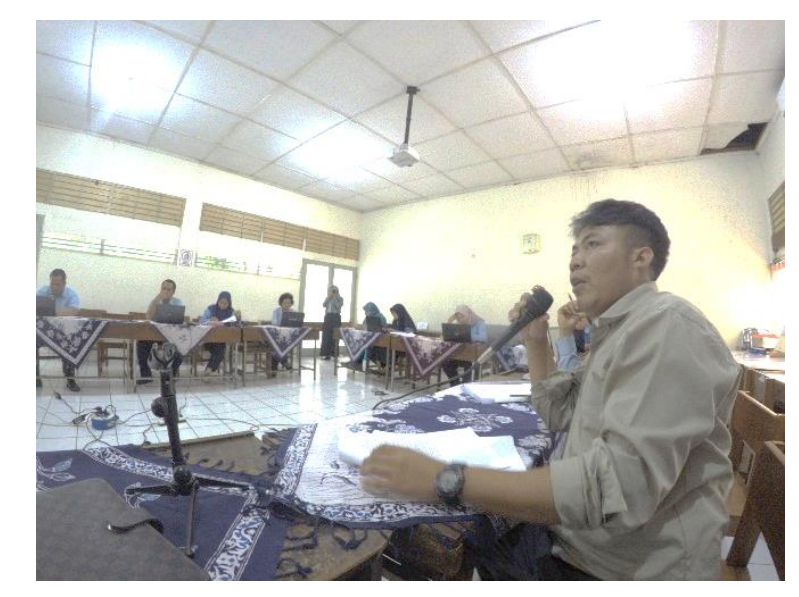

Gambar 2. Pengabdi memberikan materi pembelakan dasar artikel dan jurnal berbasis OJS

2. Pendampingan

Setelah memperoleh bekal pengetahuan dan kecakapan dalam membuat artikel dan seluk beluk jurnal OJS untuk publikasi karya tulis ilmiah, peserta pelatihan didampingi untuk merancang sebuah tulisan / artikel bersumber dari hasil PTK. Peserta dibagi menjadi beberapa kelompok untuk menyusun artikel mulai dari pembuatan judul yang sesuai dan memecah variabel penelitian agar dapat dibuat dalam beberapa artikel. Kemudian tahap membuat pendahuluan yang bersumber pada latar belakang penelitian, setelah itu memasuki tahap penyusunan metode yang menceritakan bagaimana metode penelitian yang dipakai dalam PTK. Hasil dan pembahasan dibuat secara singkat dan padat dengan mengambil intisari penelitian, kemudian yang terakhir adalah penarikan simpulan hasil penelitian yang dituangkan kedalam artikel. Guru memerlukan kecakapan atau strategi untuk meringkas dan memilih unsur penting mana saja yang perlu dimasukkan kedalam suatu artikel. Hal yang nampak sederhana namun memerlukan kejelian, karena meringkas ratusan halaman menjadi beberapa halaman sangat sulit dilakukan, sehingga banyak guru yang masih merasa kesulitan. Beberapa guru bahkan masih mengalami kesulitan dalam mengoperasikan computer, sehingga pengabdi harus mendampingi secara perlahan, salah satu peserta pelatihan adalah guru yang mempunyai hambatan penglihatan / tunanetra. Pengabdi harus mendampingi dan 
membantu menyeleksi bagian penelitian yang perlu dimasukkan kedalam artikel. Beberapa guru yang membawa hasil penelitian (printout) diarahkan pengabdi untuk mencoret, menggaris atau menandai bagian dari penelitian yang dirasa penting. Sehingga kegiatan pendampingan ini tidak hanya memfasilitasi yang siap teknologi, namun juga tetap memperhatikan pada gutu yang gagap teknologi. Sehingga semua sasaran atau guru dapat menuai kegiatan pelatihan ini.

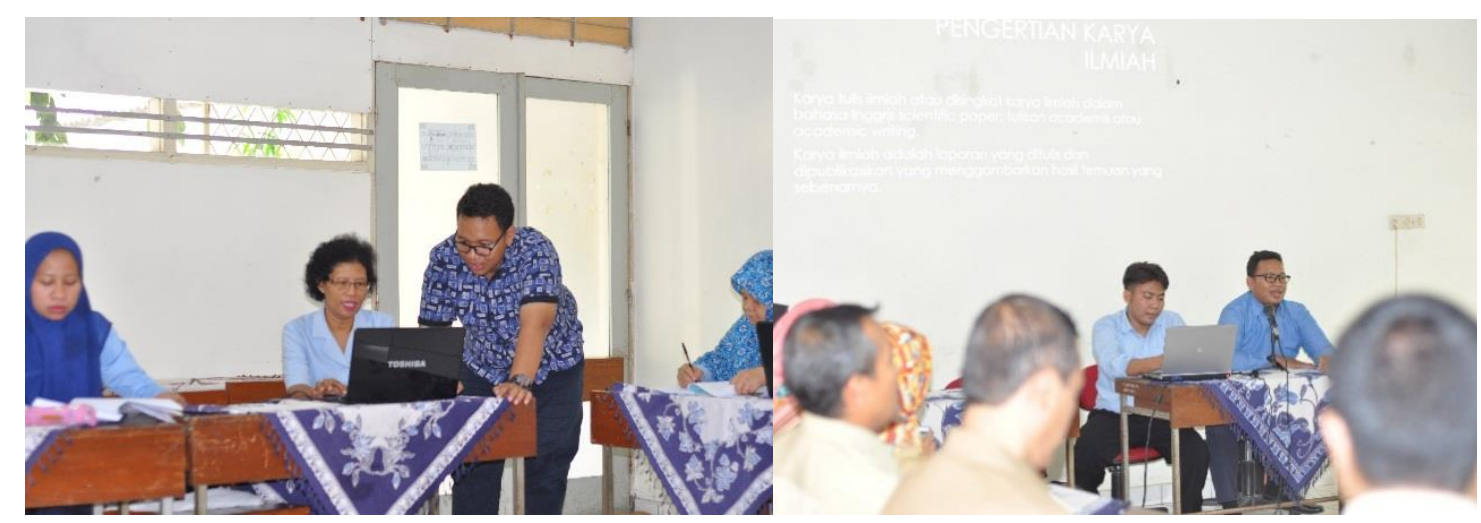

Gambar 3. Pengabdi memberikan pendampingan penyusunan artikel
Gambar 4. Pengabdi memberikan pelatihan materi

3. Implementasi

Implementasi hasil pelatihan publikasi jurnal diterapkan pada masing-masing peserta pelatihan. Implementasi yang dimaksud adalah, guru secara mandiri dapat membuat atau menyusun artikel penelitian ptindakan kelas. Tahap implementasi berikutnya adalah guru mampu mengupload atau submit artikel ke jurnal OJS. Pengabdi memantau perkembangan memalui portal jurnal exponential (jurnal PLB UPY) untuk melihat perkembangan proses submit artikel oleh guru-guru peserta pelatihan publikasi jurnal. Tahap implementasu ini dimaksudkan untuk mengetahui tingkat pemahaman dan ketrampilan guru setelah mengikuti pelatihan. Hasil implementasi juga mampu mengukur tingkat keberhasilan pelatihan terhadap peningkatan kemampuan guru dalam publikasi jurnal. 
4. Evaluasi

Evaluasi dalam pengabdian ini dilakukan kepada guru SLB N 1 Bantul sebagai subyek pengabdian. Evaluasi pada guru dilakukan dengan menilai aktivitas guru dalam merancang artikel hasil penelitian tindakan kelas berdasarkan gaya selingkung atau template jurnal yang telah disediakan oleh pengabdi. Instrumen yang digunakan untuk mengevaluasi guru yaitu lembar observasi yang diisi oleh kepala sekolah dan pengabdi.

Pembuatan artikel hasil penelitian tindakan kelas (PTK) pada dasarnya sama ddengan pembuatan artikel yang disajikan dalam pertemuan ilmiah/seminar (Suhardjono, 2006). Guru yang mempunyai banyak karya ilmiah yang dipublikasikan perlu diapresiasi karena dapat memberikan kontribusi pemikiran maupun hasil penelitian guna menjawab tantangan yang dihadapi guru di lingkungan Pendidikan(Yanti, Setiawan, \& Rini, 2020).

Terdapat beberapa alasan mengapa guru perlu mengembangan suatu karya ilmiah, yaitu: guru merupakan seorang insan terpelajar sebagai agen pembaharu, serta guru sebagai pendorong siswa untuk menghasilkan karya ilmiah, guru sebagai insan peneliti dalam penelitian tindakan kelas dan guru sebagai penulis karya ilmiah (Sudjana dan Laksana, 2004). Sedangkan Wening, dkk (2009) Suatu karya tulis hendaknya dibuat secara APIK, yaitu Asli atau original, Perlu atau mengantung kebermanfaatan (iusefull), Ilmiah (scientific), serta Konsisten. Guru yang pada umumnya belum memiliki kemampuan yang memadai dalam menghasilkan suatu karya ilmiah, dengan pelatihan dan bimbingan yang intensif pada akhirnya seorang guru akan mampu menghasilkan karya tulis yang memadai (Aina, dkk, 2015). Pengetahuan guru tentang karya tulis ilmiah berkaitan tentang bagaimana suatu logika guru mengenai penulisan tersebut. Penugasan penelitian tindakan kelas dan penulisan artikel ilmiah dimaksudkan agar guru sebagai tenaga profesioanal dapat melakukan perubahan demi pencapaian prestasi dalam menjalankan profesinya yang lebih baik (Hadiyati, dkk., 2017).

\section{KESIMPULAN}

Kesimpulan atas terselenggaranya kegiatan pengabdian dalam bentuk pelatihan publikasi jurnal hasil penelitian tindakan kelas di SLB N 1 Bantul adalah dimilikinya kompetensi guru dalam membuat, merancang artikel yang bersumber dari penelitian tindakan kelas secara mandiri sesuai dengan kaidah penulisan artikel. selain itu guru juga 
memiliki kemampuan untuk menggunakan teknologi informasi dan komunikasi untuk upload/submit artikel secara mandiri melalui jurnal ilmiah yang sudah menggunakan system OJS. Pelatihan ini membuat guru semakin bersemangan dan semakin giat dalam melakukan penelitian tindakan kelas dan mempublikasikan hasil penelitiannya ke dalam jurnal. Semangat ini bukan tanpa alas an, karena guru juga dituntuk membuat publikasi ilmiah untuk kenaikan jabatan/golongan.

\section{REKOMENDASI}

Berdasarkan kegiatan pengabdian yang dilakukan, pengabdi memberikan rekomendasi agar tiap forum KKG / MGMP secara berkelanjutan mengadakan kegiatan yang berkaitan dengan penulisan karya ilmiah, sehingga guru semakin banyak yang memberikan arahan serta berbagi pengalaman. Guru diharapkan tiap membuat penelitian tindakan kelas minimal harus menghasilkan artikel/publikasi jurnal ilmiah yang sudah menggunakan system OJS, sehingga dapat menambah khasanah ilmu pengetahuan bagi orang lain.

\section{UCAPAN TERIMAKASIH}

Ucapan terimakasih disampaikan kepada seluruh guru SLB Negeri 1 Bantul yang berpartisipasi dalam kegiatan pelatihan, 2) Kepala Sekolah SLB Negeri 1 Bantul yang secara terbuka, selalu mendampingi, dan memfasilitasi kegiatan pengabdian 3) Kepada LPPM Universitas PGRI Yogyakarta yang memfasilitasi, memberi support dana dan selalu memberi arahan dalam pelaksanaan pengabdian.

\section{DAFTAR PUSTAKA}

Aina, M., Bambang, H., Retni, S. B., Afreni, H., \& Sadikin, A. (2015). Pelatihan penulisan karya tulis ilmiah bagi guru-guru SMA 8 Kota Jambi. Jurnal pengabdian pada masyarakat, 30(3), 29-32.

Hadiyati, H., Fatkhurahman, F., \& Suroto, B. (2017). Pelatihan Manajemen Penulisan Karya

Tulis Ilmiah Bagi Tenaga Pendidik Di SMP N 3 Kampar Kiri Tengah. Dinamisia: Jurnal Pengabdian Kepada Masyarakat, 1(1), 122-128.

Peraturan Bersama Menteri Pendidikan Nasional Peraturan Manteri Pendidikan Nasional Nomor 35 Tahun 2010 tentang Petunjuk Teknis Pelaksanaan Jabatan Fungsional Guru dan Angka Kreditnya.

Peraturan Menteri Negara Pendayagunaan Aparatur Negara dan Reformasi Birokrasi Nomor 16 Tahun 2009 tentang Jabatan Fungsional Guru dan Angka Kreditnya.

Sri Wening, Nani Ratnaningsih, dan Titin Hera Widi Handayani. 2009. Wokrshop Penulisan Karya Ilmiah sebagai Upaya Pengembangan Profesinalisme Guru SMK. Inotek13 (2), Agustus 2009 
Sudjana, N., dan Laksana, U. 2004. Menyusun Karya Tulis Ilmiah untuk Memperoleh Angka Kredit. Bandung: Sinar Baru Algesindo.

Suhardjono. 2006. Peningkatan Karir Tenaga Kependidikan Khususnya dalam Hal Pembuatan Karya Tulis Ilmiah sebagai Kegiatan Pengembangan Profesi. Makalah disampaikan pada Temu Konsultasi dalam rangka Koordinasi dan Pembinaan Kepegawaian Pendidik dan Tenaga Kependidikan, Griya Astuti, Kementerian Pendidikan Nasional, November.

Supardi. (2007). Guru Golongan IV/a Bisa Naik Pangkat ke Golongan IV/b Menggunakan "CAR". Artikel Pendidikan. kemdikbud.go.id.

Universitas Pendidikan Indonesia. (2014). Panduan penulisan karya ilmiah 2014. Bandung: Universitas Pendidikan Indonesia.

Yanti, N., Setiawan, Y., \& Rini, D. S. (2020). The Mendeley Application Training at MGMP Bahasa Indonesia SMA / SMK in Bengkulu City. Jurnal Berdaya Mandiri, 2(1), 268-284. https://doi.org/https://doi.org/10.31316/jbm.v2i1.432 